Araştırma Makalesi • Research Article

\title{
Yerinde Yaşlanma ve Yerel Yönetim Uygulamaları: İstanbul Örneği
}

\author{
Aging in Place and Local Government Practices: The Case of Istanbul
}

Hamza KURTKAPAN ${ }^{* *}$

D 0000-0001-9815-7337
Murat ŞENTÜRK*

0000-0002-9628-6300

\section{MAKALE BİLGISİ}

Başvuru: 15. 11. 2021

Düzeltme Talebi: 24.11 .2021

Son Düzeltme: 25.11 .2021

Kabul: 07.12.2021

Online Yayım: 15.12.2021

\section{Anahtar Kelimeler: \\ Sosyoloji \\ Yaşlılık Sosyolojisi \\ Yerinde Yașlanma \\ Yerel Yönetimler \\ Sosyal Politika}

ÖZ

Yerinde yaşlanma, alışılan çevrede olabildiğince uzun süre yaşamını sürdürerek yaşlanmayı ifade etmektedir. Kentleşme süreci dolaylı biçimde yaşlıların yerinde yaşlanmalarını zorlaştırmaktadır. Kentsel alanlarda yerinde yaşlanmanın sürekliliği için bu sürecin yaşlılar için ortaya çıkardığı olumsuzlukları tespit edilmesi gerekmektedir. Yerinde yaşlanmanın gerçekleşebilmesi için yerel yönetimlerin ailenin yaşlılara yönelik bazı sorumluluklarını paylaşması gerekmektedir. Bu çalışmada, İstanbul'da ilçe yerel yönetim hizmetlerinin yerinde yaşlanma sürecine ne tür bir katkı sağladığını ortaya çıkarmak amaçlanmaktadır. Nitel araştırma desenlerinden fenomenoloji nitel araştırma deseni kullanılarak, yerel yönetim aktörleriyle 30 adet yarı yapılandırılmış görüşme yapılmıştır. Veriler betimsel analiz tekniği kullanılarak analiz edilmiştir. Yerel yönetimlerin yaşlılara yönelik hizmetler aracıllğıyla ailenin yaşlılara yönelik bazı sorumluklarının paylaşılması yerinde yaşlanma sürecine olumlu katkı yaptığı söylenebilir.

Araștırmada yerel yönetimlerin yalnız yaşayan yaşlıların ya da aile ve akrabalarıyla kalan yaşlıların bazı temel ihtiyaçlarını destekleme noktasında kritik bir role sahip olabilecekleri sonucuna ulaşılmıştır. Kentlerde yerel yönetimlerin yaşlı kişisel bakım ve sağlık hizmetleri, evlere sıcak yemek servisi gibi faaliyetlerinin yerinde yaşlanmayı kolaylaştıracağı söylenebilir. $\mathrm{Bu}$ hizmetler yaşlıların sosyal ve fiziksel çevrelerinde kopmadan yaşlanmalarına yardımcı olacaktır. Yaşlılara yönelik hizmetlerin güvenilir kaynaklar tarafından sunulması yaşlıların huzurlu, sağlıklı şekilde yaşlanabilmelerine hizmet edebilir. Bu çerçevede kamusal boyuta sahip yerel yönetimlerin yaşlı ve yaşlı aileleri ile iş birliği içerisinde yaşlılara sunacağı hizmetler yaşlların kendilerini daha güvende ve mutlu hissetmelerini sağlayacaktır. Yaşlanma sürecinin ortaya çıkardığı dezavantajlara bağlı biçimde olarak geleneksel anlamda aile bireylerinin üstlendikleri yaşlı bakımı sorumluluklarının önemli bir kısmının yerel yönetimlerce paylaşılması gerekmektedir.

\section{AB ST RACT}

Aging in place refers to aging by living in the habitual environment for as long as possible. The urbanization process indirectly makes it difficult for the elderly to age in place. For the continuity of aging in place in urban areas, it is necessary to determine the negative effects of this process for the elderly. In order for aging in place to take place, local governments need to share some of the responsibilities of the family towards the elderly. In this study, it is aimed to reveal what kind of contribution the district local government services make to the aging process in Istanbul. Using the phenomenology qualitative research design, one of the qualitative research designs, 30 semi-structured interviews were conducted with local government actors. The data were analyzed using the descriptive analysis technique. It can be said that the sharing of some responsibilities of the family towards the elderly through local governments' services for the elderly contributes positively to the aging process in place.

\footnotetext{
*1 Yazar İletişim/ Corresponding Author: Hamza Kurtkapan (Doç. Dr.), Nevşehir Hacı Bektaş Veli Üniversitesi, Sağlık Hizmetleri Meslek Yüksekokulu, Sağlık Bakım Hizmetleri Bölümü, Yaşlı Bakım Programı, Nevşehir, Türkiye 凶 hamzakurtkapan@nevsehir.edu.tr

*2 Murat Şentürk (Doç. Dr.), İstanbul Üniversitesi, Edebiyat Fakültesi, Sosyoloji Bölümü, İstanbul, Türkiye $₫$ murat.senturk@istanbul.edu.tr Kaynak Gösterimi/ Citing This Article: Kurtkapan, H. ve Şentürk, M. (2021). Yerinde Yaşlanma ve Yerel Yönetim Uygulamaları: İstanbul Örneği. Sosyolojik Bağlam Dergisi, 2(3), 01-13. doi:10.52108/2757-5942.2.3.1
} 
In this study, it has been concluded that local governments can have a critical role in supporting some of the basic needs of the elderly living alone or staying with their families and relatives. It can be said that the activities of local governments in cities, such as personal care and health services for the elderly, and hot meal delivery to homes, will facilitate aging in place. These services will help the elderly to age without being cut off from their social and physical environments. The provision of services for the elderly by reliable sources can help the elderly to age peacefully and healthily. In this context, the services that local governments with a public dimension will provide to the elderly in cooperation with the elderly and their families will make the elderly feel safer and happier. Depending on the disadvantages caused by the aging process, a significant part of the responsibilities of elderly care undertaken by family members in the traditional sense should be shared by local governments. 


\section{Giriș}

Yaşlıların mekânla ilişkisini inceleyen mekân gerontolojisi, hem kurumsal bakımı hem de yerinde yaşlanmayı ele almaktadır. Mekân gerontolojisinde iki yaklaşım öne çıkmaktadır. İlki olan "yerinde yaşlanmada", yaşlının kendi evinde kalması bağlamında sınırlı da olsa yakın çevresiyle etkileșim halinde olmasının yararlı olacağı savunulmaktadır (Esendemir, 2016, s. 412). "Kurumda yaşlanma" olarak tanımlanan ikincisinde ise yaşlıların kendi ihtiyaçlarını temin edebildikleri yerleşik bir mekâna (bakımevi, huzurevi) odaklanılmaktadır (Kalınkara ve Arpacı, 2013, s. 55). Yerinde yaşlanma sürecine konut, yerleşim yeri ve komşular gibi birimler etkili olabilmektedir. Yerinde yaşlanma çoğu kez bir evi ima etse bile bu evi içine alan fiziksel ve toplumsal çevreyi de kapsamaktadır. Dolayısıyla ev, apartman, sokak, mahalle ve hatta semt yerinde yaşlanmanın fiziksel ve toplumsal unsurları olarak kabul edilir. Yerinde yaşlanmanın aile ve topluma olumlu etkisi, bireylerin mevcut sosyal bağların devamlılığını mümkün kılmasıdır. Böylece bireylerin fiziksel ve sosyal ihtiyaçlarını karșılayarak yașam kalitesini yükseltme potansiyeline sahiptir. Dörter (2014) evlerinde yașlanan yaşlıların sosyokültürel çevre memnuniyeti ve yaşam kalitesinin yüksek olduğunu belirlemiștir. Bundan dolayı yaşlılar hasta ve zayıf düștükleri durumlarda bile gençliklerini geçirdikleri ve alışageldikleri mekanlarda yaşlanmayı sıklıkla tercih etmektedirler (Sabia, 2008; Tang ve Lee, 2011, s. 460; Smith, 2009, s. 14; Şentürk ve Ceylan, 2015). Yaşlıların yerinde yaşlanmayı tercih etmelerinin temel nedenleri arasında kendilerini güvende hissetmek arzusu gösterilmektedir (Tufan, 2003, s. 140). Kurum bakımının yüksek maliyetlerinden kurtarma etkisi yerinde yaşlanmayı aile ve kamu tarafından da tercih edilir kılmaktadır (Kalınkara ve Arpacı, 2013, s. 56-57). Yaşlı bakımında kurumsal bakım maliyetinin yüksekliğinden dolayı Türkiye ve Avrupa'da kamu politikası olarak yerinde yaşlanma teşvik edilmektedir (Ceylan, Ayar, Günel, 2015, s. 87).

Yaşlı ve ailesini kurumsal bakıma yönelten nedenleri ortaya koymak gerekmektedir. Kentsel alanlarda yaşlıları yerinde yaşlanmanın sürekliliği için bu sürecin yaşlılar için ortaya çıkardığı olumsuzlukları tespit edilmesi gerekmektedir. Yerinde yaşlanmanın psikososyal, ekonomik ve yaşlının sağlık ve güvenliği gibi konularda olumsuz yansımaları olmaktadır. Şöyle ki yerinde yaşlanma süreci hizmet sağlayıcı eș, akraba, bakıcı ve komşular üzerinde maddi ve manevi yıkım oluşturabilmektedir (Horner ve Boldy, 2008; Sixsmith ve Sixsmith, 2008). Uzun süreli kullanımdan dolayı yıpranan ve eskiyen evlerin tamir ihtiyacına rağmen; bazı yaşlıların sosyoekonomik durumlarının kötü olması, yaşadıkları mekânı yenilemelerini zorlaştırmaktadır (Renaut, Ogg, Petite, ve Chamahian, 2015, s. 1298). Eskiyen evler yașlanan insanların hayatını zorlaștırmakta ve tehlike oluşturabilmektedir. Bu evler yaşlıların birçok problem yaşamalarına (düşme vb.) neden olmaktadır. Yerinde yaşlanmanın olumsuz sonuçlarından biri de yaşlıların sosyal dünyalarının küçülmesiyle evlerine mahkûm edilmeleridir (Nair, 2005, s. 110). Bu tip olumsuzluklar ve kent mekânlarının fiziksel özellikleri yaşlıların yaşam kalitesini etkilemekte (Phlips, yeh, Chung 2005, s. 147) ve yaşlıları kurumsal bakıma yönlendirmektedir. Aile yapısında değişimler de yaşlıların, geleneksel anlamda yaşlı bakımı yerine kurumsal bakım tercihini arttırabilmektedir. Kentleșmeyle birlikte ailenin işlevleri de değişmiş̧tir (Özbay, 2015, s. 32). Buna yaşlıların aile ve toplum içerisinde yaşadıkları statü kayıpları (Palmore, 1990, s. 59-60) da eklenince yaşlılarda kurumsal bakım tercihi daha da yaygınlık kazanmaktadır.

Tablo 1: Yaşlıların Gelecekte Huzurevini Bir Yaşam Tercihi Olarak Düşünme Nedenleri, 2016

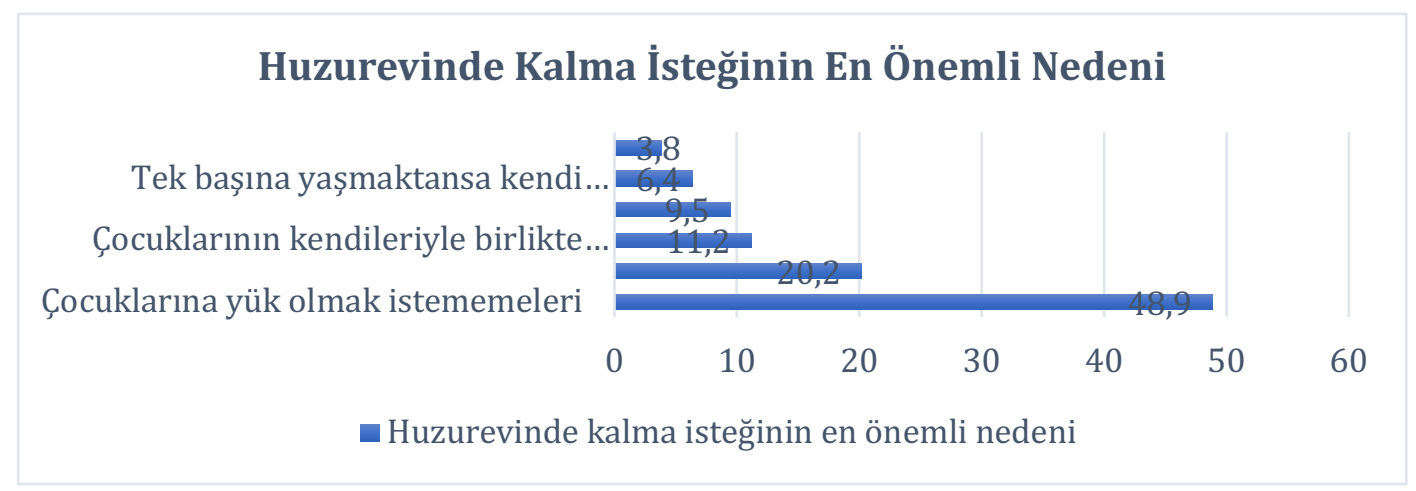

Kaynak: TÜIK, Aile Yapısı Araştırması, 2016 
Tablo 1'de görüldüğü üzere, yaşlılara huzurevinde kalmayı tercih nedenini katılımcıların yarıya yakını \%48,9 çocuklarına yük olmayı istememe olarak belirtmişlerdir. \%15'i ise çocuk, gelin ve damat gibi birinci dereceden yakınlarının kendileriyle birlikte yaşamak istememelerini göstermişlerdir (TÜİK, 2016). Ailenin diğer üyelerine yük olmama isteği, huzurevini tercihte en önemli etken olarak dikkat çekmektedir.

Ayrıca kentlerde yeni mekânlara gençlerin göç etmesiyle yaşlı nüfus eski yerleşim bölgelerinde yoğunlaşmaktadır (Palmore, 1990, ss. 59-60). Kentleşme ve göç hareketlerinin ailede tetiklediği değişimlerden diğer yaş gruplarına oranla en fazla yaşlılar etkilenmektedir. Kentleşmeyle birlikte ailedeki işlevsel değişimler (Özbay, 2015, s. 32) yaşlıların sosyal izolasyona maruz bırakılmalarına yol açabilmektedir (Ceylan, Ayar ve Güneli 2015, s. 91). Böylece yaşlı yalnızlığı görünür hale gelmektedir (Kurtkapan, 2017, s. 30). Kentli yaşlıların en önemli sorunu olarak yalnızlığı gösterilmektedir (Öz, 2010, s. 144). Ayrıca yalnızlık, yoksulluk ve kadın olmak yaşlılıktaki dezavantajlılığı katmanlaştırmaktadır (Arun, 2016). Ailenin giderek küçülmesi ve artan boşanma oranları gelecekte yalnız yaşayan yaşlıların özellikle de yaşlı kadınların artacağına işaret etmektedir (Kurtkapan, 2017, s. 32). Yaşlıların yalnızlaştırılması ve düzenli bakımlarının yapılamaması da yerinde yaşlanmanın olumsuzlukları arasında sayılmaktadır (Timmermann, 2012, ss. 24-25). Bu bağlamda yaşlılar yalnızlık ile baş edebilme adına daha fazla kamusal hizmetlere ihtiyaç duymaktadır. Yerel yönetimler kentte yaşayan yaşlıların sosyal destek ihtiyaçlarına cevap verebilen önemli birimlerdir. Yaşlıların ileri yaşlarda evlerinde, alışageldikleri sosyal çevrelerde yaşlanabilmeleri için yaşlı bakımında ailenin sorumluluklarının bir kısmını yerel yönetimlerin paylaşması gerekmektedir. Yerel yönetimler, yaşlılara evde sundukları birtakım hizmetlerle yaşlı ailelerini destekleyebilir (Öz, 2010, s. 74). Yerel yönetimlerin destek hizmetleri, bakım sorumluluğu üstlenen aile bireylerini rahatlatarak yerinde yaşlanmayı kolaylaştırabilir.

Kentlerde yaşlıların karşılaştığı engeller de yerinde yaşlanmayı zorlaştırmaktadır. Son zamanlarda bu yönde gelişen farkındalık ile kentlerde yaşlılar için kullanışlı mekânlar oluşturmak bir trende dönüşmüştür (Smith, 2009, s. 42). Dünya Sağlık Örgütü’nün geliştirdiği "Küresel yaşlı dostu kentler kılavuzunda", ev/hane düzeni ve diş alan ve binaların yaşlılar açısından düzenlenmesi önemli başlıklar arasında yer almaktadır (Şentürk, 2015, s. 8; WHO, 2007). Böylelikle kentlerin çevresel şartları, yaşlıların rahat yaşamalarına uygun hâle getirilmesi hedeflenmektedir. Bu hedef doğrultusunda engellerin azaltılması ve sosyal katılımlarının kolaylaştırılması amaçlanmaktadır. Modern kentlerde yerel yönetimlerin tele destek, evde bakım/onarım, sağlık gibi hizmetleri, yaşlıların yaşam kalitelerini arttırmaya dönük hizmet etmektedir. Bu tarz hizmetlerdeki yaygınlık kentin yaşlı dostu veya dost kent kategorisinde değerlendirilmesine ve kurumsal yaşlı bakım tercihini ötelemeye yarayabilir. Ayrıca yaşlı bakımında modern ilkeler doğrultusunda hareket edilmesi arzulanmaktadır (Özservet, 2015, s. 58). Özellikle kentsel alanlarda yaşlılara yönelik, kişisel bakım ve sağlık hizmetlerini planlama ve organize etmede yerel yönetimlere sorumluluklar düşmektedir. Zira 7. Kalkınma Planı'nda sosyal nitelikli hizmetlerin yerel yönetimlerce sunulması programa dâhil edilmiştir (Öz, 2010, s. 36). Yaşlıların yaşam standartlarını yükseltmeyi amaçlayan sosyal yardım ve hizmetler sosyal belediyecilik kapsamında değerlendirilmektedir (Akarsu, 2014). Yaşlı dostu kent kapsamında yerel yönetim hizmetlerinin yerinde yaşlanmayı destekleyici ve yaşlıların kurumsal bakım ihtiyaçlarını geciktirici etkisinden söz edilebilir. Bu ilkelere göre kentsel mekânlarda düzenleme yapma ve hizmetleri organize etme yerinde yaşlanmayı kolaylaştırmaktadır. Böylece kamunun kurumsal yaşlı bakım maliyeti dolaylı olarak düşürülmektedir.

Yerel yönetimlerin

yaşlılara yönelik

hizmetlerin nicelik ve

niteliğinin artması
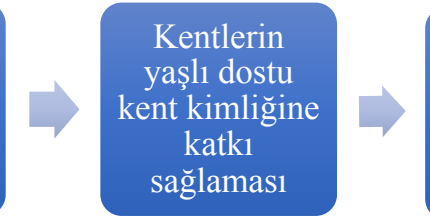

Yaşlıların

yerinde

yaşlanmalarını

kolaylaştırması
Kamuda kurumsal

yaşlı bakım

maliyetlerini

azaltması

Şekil 1. Yerel Yönetim Hizmetlerinin Yaşlı Bakım Maliyetlerine Yansıması

Kaynak: Araştırmacı tarafından çalışma bulgularından elde edilmiştir. 
Şekil 1'de görüldügü üzere kentlerde yerel yönetimlerin yaşlllara yönelik hizmetlerinin çeşit ve kalitesinin artması bu kentlerin yaşlı dostu olma kimliklerine olumlu katkı sağlayacaktır. Yaşlılar yaşlı dostu kentlerde daha kolay yerinde yaşlanacaklar ve kurumsal bakımı daha az tercih edeceklerdir. Böylece kamunun yaşlı bakım maliyetlerinin azaltılmasına dolaylı katkı sağlanmış olacaktır.

Yaşlıların kurumsal bakımı ötelemesini sağlamak için kentin tüm alanlarının yaşlı dostu haline getirilmesi gerekmektedir. Yerel yönetimler yol, kaldırım gibi yapısal özelliklerin iyileştirilmesinin yanında farklı hizmetleri sunması yerinde yaşlanmayı kolaylaştırabilir. Zira yaşlıların evlerinde temizlik ve onarımdan, kişisel bakıma kadar kendilerine ve bakım sağlayıcı ailelerine destek ihtiyaçları ortaya çlkabilmektedir (Kurtkapan, 2017, s. 205). Bu ihtiyaçların giderilmesi yaşlıların insan onuruna yakışır şekilde hijyenik, sağlıklı ortamlarda yaşlanabilmelerine katkı sağlayacaktır. Mekân gerontolojisinde, daha çok yaşlıların evlerinin fiziksel durumlarının yaşlılara uygunluğuna odaklanılmaktadır (Cook, Martin, Yearns, ve Damhorst, 2007, s. 202). Oysa konutların yer aldığı fiziksel ve sosyal çevre de (Kalınkara ve Arpacı, 2013) yaşlıların yerinde yaşlanmalarına etki etmektedir. Dolayısıyla kentsel mekânlarda yapılacak iyileștirmeler yerinde yaşlanmayı kolaylaştırabilmektedir (Smith, 2009, s. 146). Bundan dolayı yerinde yaşlanma, sadece konut olanaklarının iyileștirilmesini değil, ulaşım, rekreasyonel fırsatların, fiziksel aktivite imkânlarının topyekûn nicelik ve niteliğini arttırmayı zorunlu kılmaktadır (Wahl \& Weisman, 2003'den akt. Wiles, Leibing, Guberman, Reeve ve Allen, 2011, s. 358).

\section{Araştırmanın Yöntemi \\ 2.1 Araștırmanın Modeli}

Hipotezleri test etme yerine alanda var olan sosyal gerçekliğin hipotezlerine ulaşmaya imkân veren fenomenoloji bu nitel araştırmanın desenidir. Bu desen, çoklu bilgi kaynakları aracılı̆̆ıyla gerçek yaşam hakkında derinlemesine bilgi toplamayı olanaklı kılmaktadır (Yıldırım \& Şimşek, 2008, s. 75). Sosyal alanda var olduğu bilinen ancak yine de derinlemesine kavrayışa ihtiyaç duyulan kentte yerinde yașlanmanın imkân ve sınırlılıkları fenomenolojik nitel araștırma deseniyle incelenmiștir. Araştırmanın sonucu hem bir betimlemeye hem de araştırmacının ortaya çıkardığı temalara işaret edebilmektedir (Creswell, 2015, s. 98). Bu araştırmada da bulgular betimlenmiş ve belirli temalar ekseninde ele alınmıştır.

\section{2 Çalışma Grubu}

Araştırmanın verileri, İstanbul'un on bir ilçesinde yaşlılara hizmet sağlayan belediye personellerinden toplanmıştır. Araştırmada bu ilçelerde yerel yönetimlerin yaşlılarla ilgili uygulamalarına odaklanılmıştır. Araştırma sahasının belirlenmesinde yaşlı yoğunluğu faktörü göz önünde bulundurulmuştur. Bu bağlamda çalışmada araştırma amaçları doğrultusunda verilere ulaşmak için İstanbul'da yaşlı nüfusun en yoğun olduğu Üsküdar, Kadıköy, Fatih ve Maltepe ilçelerinde çalışılmıştır. Bu ilçelerle birlikte genel nüfus içerisinde yaşlı nüfus oranları fazla olan Beşiktaş ve Şişli ilçelerinde ağırlıklı çalışılmış olup, Ümraniye ilçesinden ikişer, Eyüp, Bağcılar, Bakırköy, Beylikdüzü ilçelerinden birer katılımcı çalışma grubuna dâhil edilmiştir. Araştırmanın çalışma grubunu yaşlılarla fazla zaman geçiren ve bundan dolayı zengin bir veri örneklerine sahip olduklarını düşündüğümüz yerel yönetimlerin yaşlı hizmet uygulayıcıları oluşturmaktadır. Araştırmada katılımcıların araştırılan konulara iliş̧kin yeterli bilgi, birikim ve deneyime sahip oldukları varsayılmaktadır. Zira bu katılımcılar okuryazar olmayanından üniversite mezununa kadar her zümreden yaşlılarla az yâda çok temasta olan sosyolog, sosyal hizmet uzmanı gibi profesyonellerden oluşmaktadır. Katılımcıların sorulara samimi ve içtenlikle cevap verdikleri düşünülmektedir. 17'si kadın, 13'ü erkek olmak üzere toplamda 30 katılımcıyla görüşülmüştür. Katılımcıların yarısı 25- 45 grubunda, diğer yarısı 45- 65 yaş grubu arasında yer almaktadır. Görüşmeler yerel yönetim merkezlerinde görüşmeyi kabul edenlerle gerçekleştirilmiştir. Araştırma için kartopu örnekleme başvurulmuştur. Katılımcıların yarısı yerel yönetimlerde yaşlı hizmetlerinde amir ve diğer yarısı da yerel yönetimlerde yaşlılara hizmet sağlayıcı memur/görevli pozisyonunda yer almaktadır. Katılımcılara atıflar metin içinde parantez içinde ve kod isimler verilerek yapılmıştır.

\subsection{Veri Toplama Aracı}

Araştırmada veri toplama sürecinde görüşme tekniği kullanılmıştır. Görüşmelerde kullanılmak üzere yarı yapılandırılmış görüşme formu geliştirilmiştir. Formun hazırlanmasında ön saha araştırmaları ve gözlemlerinin yanı sıra ilgili literatürden yararlanılmıştır. Görüşme tekniği ile ilgili profesyonellerden yerel yönetimlerin kentte yaşayan yaşlılara yönelik hizmetleri hakkında bilgiler 
alınmıştır. Görüşmelerin yanı sıra araştırmada gözlem tekniği ve doküman analizi tekniği de kullanılmıştır. Belediyelere ait yaşlılara yönelik yaşam merkezlerinde yapılan ve kent merkezlerinde gerçekleştirilen gözlemler araştırmayı güçlendirmiştir. Doküman analiziyle de veri kaynakları çeşitlendirilmiştir. Böylece çoklu teknik kullanılarak araştırmanın geçerlilik ve güvenirliliğine katkı sağlanmıştır.

\section{$2.4 \quad$ Verilerin Toplanması}

Verilerin toplama sürecinden önce çalışma yapılacak kurumlar için resmi izin yazışmaları yapıldı. Veri toplama süreci Haziran 2016'da Kadıköy ve Bağcılar ilçelerinde yapılan pilot uygulamalarla başlamış, Ağustos 2016'da sona ermiştir. Araştırmada etik kurallar çerçevesinde görüşmelere başlamadan önce, katılımcıların bilgilendirilerek onayları alınmıştır. Görüşmelerin tamamının araştırmacı tarafından yapılması, görüşmeler arasındaki bağlantıyı ve konu bütünlügünü sağlaması bakımından bir avantaj sağlamıştır. Görüşmelerin hepsinde görüşme formu kullanılmış, dört adet görüşme dışında tüm görüşmeler ses kayıt cihazı ile kayıt altına alınmıştır. Mülakatlar çoğu zaman belediyelerde ya da sosyal yaşam merkezlerinde yapılmıştır. Özellikle belediye personelleri ile yapılan görüşmeler, genelde çalışma saatleri içerisinde yapıldığından bazı görüşmeler yarım saati aşmayacak şekilde sınırlı bir zaman diliminde gerçekleştirilebilmiştir.

\subsection{Verilerin Analizi}

Çalışmada veriler, betimsel içerik analiziyle değerlendirilmiştir. Verilerin analizi aşamasında ses kayıtları deşifre edilerek araştırmacı tarafından hazır hâle getirilmiştir. Görüşmeler bire bir çözümlenip kodlanarak, kategorilere ve temalara ulaşılmıştır. Bu çerçevede, durumun bağlamı ortaya konulduktan sonra temalar analiz edilmiştir (Creswell, 2015, s. 101). Katılımcıların kimliklerini korumak amacıyla onlara birer kod verilmiștir.

\section{Bulgular}

Bu çalışmada kentsel mekânlarda yaşlılara yönelik bazı kurumsal hizmetlerin yerinde yaşlanmaya katkısı incelenmiştir. Bu doğrultuda yaşlılara yönelik yerel yönetim uygulamalarının, yaşlıların huzurevi gibi kamuya ait kurumsal bakım tercihini ötelemeye katkısı değerlendirilmiştir. Evde sağlık uygulamaları, kişisel bakım, tele destek ve evde sıcak yemek yardımı gibi yerel yönetim hizmetlerinin yaşlıların yerinde yaşlanmalarına etkisine bakılmıştır. Yaşlılara yönelik yerel yönetim uygulamalarının kamunun kurumsal yaşlı bakım maliyetlerini düşürücü etkisinden söz edilebilir. Hem aktör olarak yaşlıların hem de yapıyı temsilen devletin yaşlılara yönelik yerel yönetim hizmetlerinden nasıl etkilendiği, ikili bir düzlemde değerlendirilmiştir. Çalışmada yaşlıların ve kamunun öncelikli tercihlerinin yerinde yaşlanma lehinde olduğuna dair bulgulara ulaşılmıştır.

Yaşlı bakımında aile, devlet, STK ve bir aktör olarak yaşlı bireyin ne kadar sorumluluk alması gerektiği tartışma konudur. Türkiye'de yașlılara genellikle kendi aileleri bakmaktadır (Oğlak, Canatan, Tufan, vd., 2017, s. 566). Aile belirtilen diğer birimlere oranla bu konuda daha fazla sorumluluk almaktadır. Bireyselleşmenin arttığı günümüz kentlerinde yaşlıların aile içerisindeki geleneksel konumları değişmektedir. Modern toplumda yaşlıların aile dışında kurumsal kaynaklara ihtiyaçları artabilmektedir. Bazı katılımcılara göre yaşlı bakımının kamuya ait maliyeti oldukça arttırmaktadır. Yerinde yaşlanma bu maliyeti düşürmek için olabildiğince uzun süreli kılınmalıdır. Sosyal politika olarak teşvik edilen yerinde yaşlanma pek çok açıdan yaşlıların da tercih ettiği bir durumdur. Bu tercihin şekillenmesinde, kamuya ait huzurevlerine yönelik yaygın olumsuz algı ve yaşlıların özgürce yaşayabilme istekleri etkili olabilmektedir.

\subsection{Uzlaşılan Bir Tercih Etiği Olarak Yerinde Yaşlanma}

Mekân gerontolojisinde yaşlıların yaşam yeri tercihleri kurumda ve yerinde yaşlanma ikiliği içerisinde ele alınmaktadır. Çalışmada yaşlıların kurumda kalma yerine yerinde yaşlanabilmeyi tercih ettiklerine yönelik bulgulara ulaşılmıştır. Katılımcılardan birisi yaşlıların alışageldiği sosyal çevreden kopmadan yaşama tercihini "yaşlılar aileyle (birlikte) kalmayı, huzurevinde kalmaya tercih ederler." (01, E, 40, BA, Psikolog) ifadesiyle belirtmiştir. Yaşlıların yerinde yaşlanma istekleri psikolojik ve sosyal nedenlerle dayanmaktadır. Kurumsal bakımla ilgili kötü söylenti ve olumsuz yargılar sosyal nedenler arasında iken, yaşlıların özgürlüklerine düşkün olmaları, özel alan oluşturma istekleri psikolojik nedenler arasında sayılabilir. Yaşlıların yerinde yaşlanmayı tercih etmelerinde, "huzurevini tercih etmemelerinin sebebi olarak toplumsal önyargı" (11, E, 41, HS, SHU) öne çıkmaktadır. "Huzurevini daha zavallı bulma" (10, K, 45, BA, Sosyolog), "yemeklere ilaç katılıyor gibi bir takım kötü (lük temalı) hikâyeler" bu olumsuz algıyı pekiştirmektedir. Huzurevinde yapılan 
araștırmalarda da yaşlılar evlerini ve mahalle yaşamını özlediklerini ifade etmektedirler (Serdal, Düzen ve Polat, 2017, s. 522). Bazı katılımcılar yerinde yaşlanmayı kurumda yaşlanmaya tercih etmekte, aynı zamanda daha özgür yaşama istekleri öne çıkmaktadır. "Huzurevi kurallı ve başkalarına bağlı kalınan bir yer" (10, K, 45, BA, Sosyolog) olduğundan yaşlılarca tercih edilmemektedir. Ayrıca yerinde yaşlanma, kurumda yaşlanma ikiliği içerisinde yaşlıların özel alan oluşturma isteği onları eve yöneltebilmektedir. "Evde olmak, kendi kişisel alanını yaratıyor olabilmek önemli bir şey o yüzden huzurevine gitmek istemiyorlar" (02, E, 32, HS, SHU). Zira "kurumsal bakım, özel hayat hakkı tanımayan bir yerdir." (02, E, 32, HS, SHU).

Görüşme yapılan bazı yerel yönetim uzmanları, yerinde yaşlanmanın aynı zamanda kurumsal bir tercih olduğunu da vurgulamıştır. Temel gerekçe olarak kurumsal bakım maliyetinin yüksekliği gösterilmektedir. "Huzurevi maliyetli bir şey; 2500- 3000 TL kişi başı maliyeti var" (11, E, 41, HS, SHU). Bu çerçevede, yaşlı bakımında ailenin desteklenerek geleneksel yaşlı bakım modelinin önemi vurgulanmıştır. Bu yüzden, "huzurevi önerilmiyor, yaşlıların olabildiğince kendi ayakları üzerinde durmaları sağlanmaya çalışllıyor" (13, E, 45, BA, Müdür). Böylece yaşllların kendi kaynaklarıyla bakım hizmeti alabildikleri yerinde yaşlanma önerilmektedir. "Yavaş yavaş bu maliyeti azaltarak yaşlıyı evinde destekleyerek yerinden etmeyen" (11, E, 41, HS, SHU) çözümler önerilmektedir. Ancak bu çözümler, yaşlıların yerinde yaşlanabilmesine katkı sağlayacak fiziki ve sosyal alt yapının güçlendirilmesinden geçmektedir. Çözüm önerileri yaşlı bakımında ailenin geleneksel anlamda yaşlı bakım pozisyonunun devamlılığına katkı sağlaması yönündedir. Yüksek maliyetli huzurevi hizmetine ihtiyacı azaltabilmek kamunun genel yaşlı bakım maliyetini azaltmaya dolaylı katkı sağlayacaktır.

Katılımcılardan birisi yerel yönetim dâhil diğer kurumların yaşlı bakımında temel rol almak yerine aileyi destekleyici bir rol üstlenmesi gerektiğini belirtmektedir. Kentleşme yaşlıların bakımında ailenin yükünü arttırmasını gerekçe göstermektedir. Katılımcı ailenin dönüştüğünü ve yaşlıyı evde tutmak istememe durumunun giderek yaygınlık kazandığını ifade etmiştir. "Eskiden (ailede) yaşlıya bakım yapılmadığında toplumsal baskı ile karşılanırdı, annesine bakmıyor, huzurevine verdi, sokağa attı, falan gibi şeyler derlerdi, şimdi toplum bunları daha çok kanıksadı" (01, E, 40, BA, Psikolog). Ailenin değiştiğine dikkat çeken bu katılımcı kentsel alanda yaşlı bakımının ailenin tahammülünün ötesine geçmeye başladığına dikkat çekmiştir. Bu noktada, özellikle yerel yönetimlere büyük sorumluluklar düştüğünü belirtmektedir. Ailede yaşanan değişimlerin yerinde yaşlanmayı zorlaștırdığı söylenebilir. Ailede yaşanan bu yapısal değişimler, ailenin yerel yönetimlerce desteklenmesini gerekli kılmaktadır. Aile ve akrabalarıyla birlikte yaşayan yaşlılar için ailenin yaşlı bakım sorumlulukları paylaşılması aile yanında yaşlanabilmeye yardımcı olmaktadır. Böylece aile ve yaşlının kendisinde olası bir kurumsal bakım isteğini ötelenebilmektedir. Bu çerçevede yerel yönetimlerin yaşlı bakımı konusunda aileleri desteklemesi gerektiği ileri sürülebilir. Yerel yönetimlerin yaşlılara yönelik olarak sağlık ve sosyal destek hizmetleri yaygınlık göstermektedir.

Yerinde yaşlanma, bireysel tercih yanında kamunun sosyoekonomik nedenlerle tercih ettiği bir süreçtir. Ancak yerel yönetimlerce yaşlı bakımında ailenin belirli sorumluluklarını paylaşması gerekmektedir. Huzurevine gidişi erteleme ve yerinde yaşlanma yüksek maliyetli sosyal yardım hizmet ihtiyacını azaltmaktadır. Yerinde yaşlanma, fiziki ve sosyal alt yapıyı güçlendirmekten geçmektedir. Yaş ilerledikçe ev temizliği, hijyen gibi ihtiyaçlar öne çıkmaktadır. Bundan dolayı yaşlıların huzurevini tercih etme gerekçelerini karşılayacak hizmetleri üretebilmek önemlidir. Yerel yönetimce yapılan araştırma bir alan araştırmasının bulgularına göre; yaşlıların ev temizliği, kişisel bakım ve öz bakım ihtiyaçları tespit edilmiştir.

İleri yaştakilere yönelik belediyelerden birinin yapmış olduğu araştırmada onlara yaşlılık dönemindeki ihtiyaçları sorulmuştur. Katılımcı verilen cevabı şöyle özetlemiştir:

"(Yaşlılara) bu dönemde ihtiyacınız nedir" sorumuza \%30 'u ev temizliği ve hijyen ihtiyacl; \%33'ü kişisel bakım ve temizlik cevabı vermişler. Bu grubun \%28'i günlük aktivitelerini yerine getirmede öz bakımlarını yapmada tam ya da kısmen bağımlı olduklarını tespit etmiştik" (O2, E, 32, HS, SHU)."

Yerel yönetimlerin bu işleri yapmasını beklemek aynı zamanda finansal kaynaklarını düşünmeyi de gerektirmektedir. "Belediyelerin belirli sınırlılıkları var, özellikle parasal kaynak sıkıntısı bulunmaktadır" (19, K, 35, HS, Hemşire). Bu çalışmada bu hizmetlerin yapılmasının genel kamu harcama maliyetlerini düşürücü etkisine dikkat çekilmektedir. Zira yerel yönetimlerin bu tarz 
hizmetlerinin kurumda bakım gibi büyük maliyetli sosyal destek ihtiyacını ortadan kaldırarak ya da öteleyerek kamu bütçesine dolaylı katkı sağlamaktadır.

Çalışmada İstanbul'da ilçe belediyelerinin yaşlılara yönelik bahsedilen hizmetleri tespit edilmeye çalışılmıştır. Yerel yönetimlerin yaşlı hizmetleri genelde evde sağlık, kişisel bakım, evin bakım ve onarımı, ulaşım, sosyal kültürel hizmetler şeklinde sıralanabilir. Bu hizmetler yaşlıların yerinde yaşlanmalarını güçlendirmeye etkisi çerçevesinde değerlendirilmiştir. Bu çerçevede ilk olarak değerlendirilen tele destek hizmetlerinin özellikle birinci dereceden bakım konusunda dezavantajlı kesimler için önemli olduğu görülmüştür. Zira bu kesimin önemli bir kesimini oluşturan yalnız yaşayan yaşlılarda "başıma bir şey gelir korkusu" (02, E, 32, HS, SHU) ve "evde yalnız ölürsem beni kimse bulamaz korkusu var" (13, E, 45, BA, Müdür). Yazgan yaşlıların kırılganlıklarına dikkat çekmektedir (Yazgan, 2017). Buton hizmeti yaşlıların bu tarz kaygılarını azaltarak yalnızlıkla baş edebilmelerinde işlevseldir. Bu hizmet bütünlüklü bir sistem dâhilinde sağllk kayıtlarını tutabilmeyi ve ileri yaşlılara sağllk konusunda yerel yönetim aktörlerinin daha etkin ve verimli hizmet sağlayabilmelerine de kolaylık sağlamaktadır. Bu uygulama bazı yalnız yaşayan yaşlılarda kurumsal bakım tercihlerinin önüne geçilebilmektedir. Yaşlllara buton hizmetinin yanında evde bakım ve sağlık hizmetlerinin varlığı tespit edilmiştir. Evde bakım hizmeti içerisinde kişisel bakım, eve sıcak yemek servisi, evde tamirat onarım hizmetleri bașta gelmektedir.

\subsection{Yaşlılara Yönelik Evde Bakım Hizmetleri}

Bazı katılımcılar, yaşlı bakımında, yerel yönetimlerin evde bakımla ilgili sorumluluklarının netleştirilmesi gerektiğini belirtmektedirler. Zira yaşlı bakımında, basit düzeyde bakımdan Parkinson gibi ileri derecede hasta bakımına kadar çeşitliğe dikkat çekilmektedir. Basit evde bakımın bileșenleri evde sağlık ve kişisel bakımdır. Yerel yönetimlerin evde bakım hizmetleri kapsamında kuaförlük ve tırnak kesim hizmetleri bulunmaktadır. Kuaförlük hizmeti yaşlıların kişisel öz saygılarının arttırmakta ve kendilerini değerli hissetmelerine katkı sağlamaktadır. Kimi yaşlılar için kişisel bakımında tırnak kesimi önemli bir hizmettir. Zira "bazı yaşlllar eğilmekte, tırnak kesmekte zorlanmaktadırlar" (08, K, 34, HS, SHU). Yaşlıların kendi imkânlarıyla karşılayamadıkları tırnak kesimi gibi fiziksel ihtiyaçlarının karşılanması yerinde yaşlanmaya katkı sağlayabilmektedir. Ayrıca yerel yönetimlerin evde bakım hizmetleri kapsamında yaşlı hasta banyosu hizmetleri de bulunmaktadır. Ancak bazı yaşlıların normal banyo talepleri de olmaktadır. Bu talepler çoğu zaman kabul edilememektedir. $\mathrm{Bu}$ hizmeti karşılamada yetersizlik kurumsal bakıma yönlenme/yönlendirme sebebi olabilmektedir. Bunun önüne geçebilme adına bu konuda uzman personellerin istihdam edilmesi gerekmektedir. Yaşlıların sağlıklı bir şekilde yerinde yaşlanmasını kolaylaştırabilir.

Yerel yönetimlerin yaşllara kişisel bakım hizmetlerinin yanında evde temizlik hizmetleri bulunmaktadır. "Bedensel olarak buna (evini temizlemeye) gücü yok, temizlikçi tutamıyor onu biz destekliyoruz" (15, E, 45, BA, Müdür). Bu çerçevede halılar, yerler silinmekte, evlerin genel temizliği yarım günlük mesai ile yapılmaktadır. Yaşlılar için insan onuruna yakışır şekilde yerinde yaşlanabilmeleri adına evde temizlik hizmeti önemlidir. Böylece yaşlıların sağlıklı ve kendileriyle barışık, güvenli, huzurlu ortamlar olarak mutlu bir şekilde yerinde yaşlanmaları desteklenebilir. Yaşlılar için güvenli bir ortam tesis etmek önemli bir gündem maddesi haline gelmiştir (Yazgan ve Kurtkapan, 2020, s. 374).

Yerel yönetimlerde yaşlı bakım hizmetinde diğer bir bileșen olarak ihtiyaç duyulan hallerde bakım onarım hizmeti bulunmaktadır. "Ev kendisine aitse senede bir defa boyası badanası yapılıyor. Varsa (evde) tadilat tamirat işleri, elden geçiriliyor" (15, E, 45, BA, Müdür). "Yaşlı bir teyze musluğu bozuksa prizi çalışmıyorsa kendi yapabileceği şeyler değil, onu (belediye olarak biz) yapıyoruz" (13, E, 45, BA, Müdür). Bu hizmetler doğrultusunda yalnız ve ihtiyaçlarını kendi karşılayamayan yaşlıların yaşamları kolaylaştırılarak onların ve yakınlarının yerinde yaşlanma tercihleri güçlendirilmektedir. Katılımcılardan bazısı yerel yönetimlerde yaşlıların yaşam alanlarındaki küçük çaplı onarım hizmetlerinin yanında büyük çaplı onarım hizmetlerinin olduğunu da belirtmişlerdir. Evde musluğun tamirinden evin çatısının onarılmasına kadar pek çok durumda yerel yönetimler ihtiyaç sahibi yaşlılara destek olabilmektedir. Bu hizmetler yaşlılar için hem bir güven hem de bir rahatlık kaynağıdır. 


\subsubsection{Evde Sicak Yemek Hizmeti}

Yaşlılar kimi durumda düzenli beslenememe sorunu yaşamaktadırlar. Sağlık ve bedensel gerilemelerle birlikte vücudun ihtiyacı olan gıdaları alabilmede bazı yaşlılar yoksunluk yaşayabilmektedir. Bazı katılımcılar yaşlıların yararlanabileceği evde sıcak yemek servisinden söz etmiş̧lerdir. "Evde kendi yemeğini yapamayan yaşlların yemeğini kendi aşevimizde pişirerek götürüp vermekteyiz" (01, E, 40, BA, Psikolog). Bu hizmet yaşlının kendisini ve/veya ondan sorumlu olup da çeşitli nedenlerde yanında bulanamayan yakın akrabalarını rahatlatmaktadır. Yerel yönetimlerin yaşlıların evde yaşlanabilmelerine dönük hizmetlerinin başında evlerine sıcak yemek hizmeti gelmektedir. Yemek hizmetinde özellikle kadın yaşlıların evde ne yemek yaparım telaşının önüne geçilmektedir. Zira "yaşlılar yemek yaparken vakitlerinin çok büyük bir kısmını kaybediyorlar. (Bazen de yaşlı yemek yaparken) mutfakta kazalara sebebiyet verebiliyor" (02, E, 32, HS, SHU). Evde yemek hizmetiyle bu tarz olası kazaların önüne geçilebilmektedir. Yaşlıların sosyoekonomik düzeylerine bakılmaksızın yemek servisinden yararlanabilmesi özellikle ileri yaşlı ve yalnız kalan, yemek konusunda desteği olmayan yaşlıların sağlıklı ve düzenli beslenebilmeleri adına yerel yönetimlerin evlere yemek hizmeti önemli bir eksiği kapatmaktadır. "Aslında baktığımızda yaşlılar için aşevi konusu önemli ve gerekli bir şeydir" (02, E, 32, HS, SHU). Eve yemek hizmeti yalnız yaşayan yaşlların ihtiyaçlarını gidermenin yanında sosyalleşme, kamudan muhatap bulma ve dertleşme fırsatı sunmaktadır. Sıcak yemek hizmeti özellikle yalnızlık çeken yaşlıların ilaçlarını düzenli alabilmelerini sağlayarak ve yemek yaparken oluşacak riskleri azaltarak kurum bakımına yönelme eğilimi zayıllatabilmektedir. Böylece yemek ihtiyacı karşılanan yaşlıların yerinde yaşlanmaları kolaylașabilmektedir. Bazı katılımcılar, yerel yönetimlerin beslenme hizmetlerinin yanı sıra sağlık hizmetlerinden de söz etmişlerdir. Yaşlıların sağlık hizmetlerine duydukları ihtiyacın karşılanması yerinde yaşlanma için kritik bir öneme sahiptir.

\subsubsection{Evde Sağlık Hizmetleri}

Yerel yönetimlerin tüm yaş gruplarını dolayısıyla yaşlıları kapsayan pek çok sağlık hizmeti bulunmaktadır. Fiziksel ve bedensel gerilemelere bağlı biçimde sağlıkta bozulmaların neticesi olarak yaşlılar diğer yaş gruplarına oranla daha fazla sağlık hizmetlerinden yararlanmaktadır. Acil ambulans, hasta nakil hizmetleri bu hizmetlerin başında gelmektedir. Bu hizmetlerin en önemli ve en hizlılarından "evde pansuman hizmeti, serum takma, evde doktor muayenesini hizmetleri bulunmaktadır" (06, K, 45, BA, Doktor). Telefonla doktorlara tıbbi danışma hizmetinin de sunulduğu tespit edilmiştir. Sağlıkla ilgili kaygıların daha yüksek düzeyde olduğu yaşlıların ulaşabilecekleri ve danışabilecekleri birimlerin olması rahatlatıcı olabilmektedir. Ayrıca bazı katılımcılar tarafından yerel yönetimlerin sağlık hizmetleri kapsamında tansiyon, şeker ölçümü, sağlıkla ilgili bilgilendirme ve uzman doktorların sunduğu seminer hizmetlerinin verildiği belirtilmiștir. Bazı yerel yönetimlerde psikolojik destek, diyetisyen ve evde fizyoterapi hizmetleri de sunulmaktadır. Aynı zamanda bu kapsamda yatalak hastalara hasta yatağı, havalı yatak verme ve evde hasta yatak banyosu hizmetleri de verilebilmektedir.

Yaşlılarda ve aile bireylerinde sağllk hizmetlerini düzenli alabilme kaygısının olduğu belirtilmiştir. Bazı yaşlılar ya da onlardan sorumlu bireyler bu hizmetleri daha etkili şekilde alabileceklerini düşünebildikleri kurumsal bakımı tercih edebilmektedir. Yerinde yaşlanma süresini uzatabilme adına yaşlıların ve ailelerin sağlıkla ilgili temel kaygılarının azaltılması gerekmektedir. Bu doğrultuda yerel yönetimlere de sağlıkla ilgili diğer kamusal kurumlarla birlikte çeşitli görev ve sorumluluklar düşmektedir.

\subsection{Yaşlılara Yönelik Ev Dışında Bakım Hizmeti}

Kentte yaşayan yaşlıların bakımında ailelere önemli sorumluluklar düşmektedir. Metropollerde bazı ailelerde bakım konusunda yetersizlikler daha fazla görülmeye başlanmaktadır. Kentsel koşullarda ailelerin yaşlı bakımında yalnız bırakılmaması gerekmektedir. Bu konuda yerel yönetimlerin önemli bir paydaş olması gerekiyor. Yerel yönetimlerin aileler sağlayacağı yaşlı bakım desteğinin tamamı evde sağlanamayacaktır. Bunun için belediyeler yaşlılara günün belirli saatlerde gidilebilecekleri mekanlar inşa etmelidirler. "Vatandaş, aile yaşantım bitti diyor, yaşlı hastaya bakmak çok sıkıntılı bir şey, gündüz bakım evi olsun diyor" (23, K, 40, HS, Hemşire). "Alzhemeir gündüz bakım yeri için çok talep var, ailelerin özellikle kadının evdeki konumunu etkiliyor" (07, K, 27, HS, Sosyolog) "Özellikle, (evde yaşlıya bakan kadın) kuaföre gitmek, pazar alışverişini yapmak için yaşlıyı güvenle bırakabileceği bir yer arıyor" (21, K, 32, BA, SHU) Modern ailede yaşanan değişimler yaşlı bakımında çeşitli olumsuzlukları beraberinde getirmiştir. Özellikle kadınların ücretli işgücünde yoğun 
çalışmaları ailedeki yaşlının ihtiyaçlarının karşılanmasında bir boşluk yaratmıștır. Yerel yönetimlerin açacağı gündüz bakım evleri, evde bakımı zorlaşan yaşlılar için bakım desteği veren aile bireylerinin yükünü azaltacaktır. Sosyal yașam evleri, gündüz bakım yerleri benzeri sosyal alanların yaşlıların mahallerinde yaşlanabilmelerinde yardımcı olacağı düşünülmektedir.

İlave olarak, yerel yönetimlerin ilgili birim müdürlükleri çerçevesinde yaptıkları sosyal ve kültürel hizmetler bulunmaktadır. Bu hizmetler, yaşlıların arkadaş edinme, sosyalleşme gibi ihtiyaçlarını karşılamaktadır. Sosyal faaliyetler yaşlıların kentte yalnızlığını azaltarak onların kurumsal bakım tercihlerini ötelemelerine dolaylı yoldan yardımcı olmaktadır. Yerel yönetimlerin sosyal hizmetleri arasında gezi, sinema ve tiyatro hizmetleri başta gelmektedir. Yaşlıların yerinde yaşlanma tercihlerinin sürekliliği adına onların bireysel talepleri de karşılanabilmelidir. Bu çerçevede gündüz bakım evi ya da bakım veren aile bireylerine yönelik belediyelerce verilecek olan periyodik destek hizmeti önemli bir boşluğu dolduracaktır. Kendi içerisinde çeşitlilik gösteren bakım merkezlerinin her mahallede açılması için yerel yönetimlere sorumluluk düşmektedir.

\section{Sonuç ve Öneriler}

Kentlerde yaşlılara yönelik yerel yönetim hizmetlerinde çeşit ve kalite arttıkça yaşlı dostu kent kimliği de belirginleşecektir. Bu hizmetlerin kentlere yaşlı dostu kimliği kazandıracağı dolayısıyla kentlerde yerinde yaşlanmanın kolaylaşacağı düşünülmektedir. Yaşlıların ev ve aile çevresinden uzaklaşmadan ihtiyaçlarının karşılanabilmesi kamunun genel yaşlı bakım maliyetlerini azaltacaktır. Yaşlların yerinde yaşlanıp kurumsal bakım tercihini ertelemeleri adına öncelikle hem yaşllarda hem de onların bakımlarından sorumlu aile bireylerinde kurumsal bakıma yönelme/yöneltmenin nedenlerini anlamak gerekmektedir. Yaşlıların çeşitli nedenlerle bulundukları evlerde/çevrede koşulların ağırlaşması ve buna yaşlıların fiziksel yetersizliklerinin eşlik etmesi kurumsal bakıma yönelme eğilimini güçlendirebilmektedir. Yaşlıların sosyal yaşamlarında bir olumsuzlukla karşılaşma korkuları, yalnız ölme kaygısı, sosyalleşme isteği kurumsal bakımı tercih etmeyi gündeme getirmektedir.

Sosyal, kültürel, ekonomik ya da fizyolojik açıdan insan onuruna yakışır şekilde yerinde yaşlanma tüm bireylerin hakkıdır. Yerel yönetimler yalnız yaşayan yaşlıların ya da aile ve akrabalarıyla kalan yaşlıların bazı temel ihtiyaçlarını destekleme noktasında kritik bir role sahiptir. Kentlerde yerel yönetimlerin yaşlı kişisel bakım ve sağlı hizmetleri, evlere sıcak yemek servisi gibi faaliyetlerinin yerinde yaşlanmayı kolaylaştıracağı söylenebilir. Bu hizmetler yaşlıların sosyal ve fiziksel çevrelerinde kopmadan yaşlanmalarına yardımcı olacaktır. Yaşlılara yönelik hizmetlerin güvenilir kaynaklar tarafından sunulması yaşlıların huzurlu, sağlıklı şekilde yaşlanabilmelerine hizmet edebilir. Bu çerçevede kamusal boyuta sahip yerel yönetimlerin yaşlı ve yaşlı aileleri ile iş birliği içerisinde yaşlılara sunacağı hizmetler yaşlıların kendilerini daha güvende ve mutlu hissetmelerini sağlayacaktır.

Sosyoekonomik düzeylerine bakılmaksızın her yaşlının bakım, temizlik, sağlık ve yemek hizmeti gibi temel ihtiyaçlarının giderilmesinde ve sosyal destek sağlanmasında aile ve yerel yönetim birimlerinin birlikte hareket etmesinin daha verimli olacağı düşünülmektedir. Yaşlanma sürecinin ortaya çıkardığı dezavantajlara bağlı biçimde olarak geleneksel anlamda aile bireylerinin üstlendikleri yaşlı bakımı sorumluluklarının önemli bir kısmının yerel yönetimlerce paylaşılması gerekmektedir. 
Ek 1. Katılımcı Listesi

\begin{tabular}{|c|c|c|c|c|}
\hline Katılımcı Kodu & Cinsiyet & Yaş & İlçe & Mesleği \\
\hline 01, E, 40, BA, Psikolog & $E$ & 40 & Maltepe & Şef/ Psikolog \\
\hline 02, E, 32, HS, SHU & $\mathrm{E}$ & 32 & Beşiktaş & Sosyal Hizmet Uzmanı \\
\hline 03, K, 30, HS, SHU & $\mathrm{K}$ & 30 & Beşiktaş & Sosyal Hizmet Uzmanı \\
\hline $04, \mathrm{~K}, 28, \mathrm{HS}, \mathrm{SHU}$ & $\mathrm{K}$ & 30 & Beşiktaş & Sosyal Hizmet Uzmanı \\
\hline 05, K, 28, HS, Psikolog & $\mathrm{K}$ & 28 & Beşiktaş & Psikolog \\
\hline 06, K, 45, BA, Doktor & $\mathrm{K}$ & 45 & Beşiktaş & Şef/ Doktor \\
\hline 07, K, 27, HS, Sosyolog & $\mathrm{K}$ & 27 & Kadıköy & Sosyolog \\
\hline 08, K, 34, HS, SHU & $\mathrm{K}$ & 34 & Kadıköy & Sosyal Hiz. Uzm. \\
\hline 09, E, 57, BA, Müdür & $E$ & 57 & Kadıköy & Müdür \\
\hline 10, K, 45, BA, Sosyolog & $\mathrm{K}$ & 45 & Şişli & Sosyolog/ Şef \\
\hline 11, E, 41, HS, SHU & $E$ & 41 & Şişli & Sosyal Hizmet Uzmanı \\
\hline 12, E, 55, BA, Emekli & $\mathrm{E}$ & 55 & Şişli & Lokal Sorumlusu \\
\hline 13, E, 45, BA, Müdür & $E$ & 45 & Üsküdar & Müdür. \\
\hline 14, K, 60, BA, Emekli & K & 60 & Üsküdar & Müdür \\
\hline 15, E, 45, BA, Müdür & $E$ & 45 & Eyüp & Müdür \\
\hline 16, E, 45, BA, Müdür & $E$ & 45 & Fatih & Müdür \\
\hline 17, K, 50, BA, Doktor & $\mathrm{K}$ & 50 & Beylikdüzü & Lokal Sorumlusu \\
\hline 18, K, 40, HS, H. İlişkiler & $\mathrm{K}$ & 40 & Bağcılar & H. İlişkiler Uzmanı \\
\hline 19, K, 35, HS, Hemşire & $\mathrm{K}$ & 35 & Maltepe & Hemşire \\
\hline 20, E, 40, BA, Müdür & $\mathrm{E}$ & 40 & Şişli & Müdür/ Avukat \\
\hline $21, \mathrm{~K}, 32, \mathrm{BA}, \mathrm{SHU}$ & $\mathrm{K}$ & 32 & Eyüp & Sosyal Hizmet Uzmanı \\
\hline 22, E, 60, BA, Doktor & $\mathrm{E}$ & 60 & Bakırköy & Müdür \\
\hline 23, K, 40, HS, Hemşire & $\mathrm{K}$ & 40 & Maltepe & Hemşire \\
\hline 24, K, 42, HS, Hemşire & $\mathrm{K}$ & 42 & Maltepe & Hemşire \\
\hline 25, K, 42, BA, Müdür & $\mathrm{K}$ & 42 & Ümraniye & Müdür/Avukat \\
\hline $26, \mathrm{~K}, 45, \mathrm{HS}, \mathrm{SHU}$ & $\mathrm{K}$ & 45 & Ümraniye & Sosyal Hizmet Uzmanı \\
\hline 27, K, 65, G, Emekli & $\mathrm{K}$ & 65 & Kadıköy & Emekli \\
\hline 28, E, 65, G, Emekli & $\mathrm{E}$ & 65 & Kadıköy & Emekli \\
\hline 29, E, 68, G, Emekli & $\mathrm{E}$ & 65 & Kadıköy & Emekli \\
\hline 30, E, 68, G, Emekli & $E$ & 65 & Kadıköy & Emekli \\
\hline
\end{tabular}

Hakem Değerlendirmesi: Dış bağımsız.

Çıkar Çatışması: Yazarlar çıkar çatışması bildirmemiştir.

Finansal Destek: Yazarlar bu çalışma için finansal destek almadığını beyan etmiştir.

Peer-review: Externally peer-reviewed.

Conflict of Interest: The authors declare no potential conflicts of interest with respect to the research, authorship, and/or publication of this article.

Grant Support: The authors received no financial support for the research, authorship, and/or publication of this article. 


\section{Kaynakça/ References}

Akarsu, S. (2014). Sosyal Belediyecilik Zeytinburnu Belediyesi Örneği, Yüksek Lisans Tezi. İstanbul: İstanbul Aydın Üniversitesi.

Arun, Ö. ve Elmas, Ç. (2016). Yaşlılıkta ayrım: Çağdaş Türkiye'de yerel yönetimleri bekleyen zorluklar. Sosyoloji Dergisi, 36(2), 351-372.

Ceylan, H., Ayar, M. ve Günel, Z. (2015). Küresel ve yerel perspektiften yaşlılara yönelik sosyal politikalar ve uygulamalar. Şentürk, M. ve Ceylan, H. (Ed.),09 İstanbul'da Yaşlanmak İstanbul'da Yaşlıların Mevcut Durum Araştırması içinde (ss. 61-106). İstanbul: Açılım Kitap.

Cook, C. C., Martin, P., Yearns, M., ve Damhorst, M. L. (2007). Attachment to "place" and coping with losses in changed communities: A paradox for aging adults. Family and Consumer Sciences Research Journal, 35(3), 201-214. doi:10.1177/1077727X06296794

Creswell, J.V. (2015). Nitel araştırma yöntemleri: Beş yaklaşıma göre nitel araştırma ve araştırma deseni (2. baskı). Ankara: Siyasal Kitapevi

Dörter, S., S. (2014). Huzurevinde ya da yerinde yaşlanmayı tercih eden yaşlı bireylerde yaşadıkları çevre ile yaşam kalitesi. (Yayınlanmamış Yüksek Lisans Tezi). İstanbul: Haliç Üniversitesi, Sağlık Bilimleri Enstitüsü.

Esendemir, Ş. (2016). Türkiye'de yerinde yaşlanma ve mekân gerontolojisinin temel parametreleri. Sosyoloji Dergisi 36(2), s. 411- 429 doi.org.10.16917/iusosyoloji.284544.

Günel, Z. (2015) Dünya'da aile dostu kent örnekleri. Aile dostu kentler etüt araştırması içinde (ss. 6982). Şentürk, M. (Ed.), Ankara: T.C. Aile ve Sosyal Politikalar Bakanlığı Aile ve Toplum Hizmetleri Genel Müdürlüğü.

Horner, B. ve Boldy, D. P. (2008). The benefit and burden of "ageing-in-place" in an aged care community. Australian Health Review, 32(2), 356-65.

Kalınkara, V. ve Arpacı, F. (2013). Yerinde yaşlanma. VII. Ulusal Yaşlılık Kongresi Kitabı içinde (ss. 5460), Karabük: Karabük Üniversitesi ve YASAD.

Nair, K. (2005). The Physically aging body and the use of space. (ss. 110-117) Ageing and place: perspectives, policy, practice içinde. G. J. Andrews ve D. R. Phillips (Ed.). London: Routledge.

Oğlak, S., Canatan, A., Tufan, I., Acar, S., ve Avci, N. (2017). Long-term care in Turkey: Are we ready to meet older people's care needs? Innovation in Aging, 1(Suppl 1), 566-566.

Öz, S., C. (2010). Sosyal belediyecilik bağlamında evde bakım hizmetleri (İstanbul, Ankara ve Kocaeli Büyükşehir Belediyeleri örnekleri). (Yayınlanmamıș Doktora Tezi). Sakarya Üniversitesi, Sakarya.

Özbay, F. (2015). Aile, kent ve nüfus: Dünden bugüne. İstanbul: İletişim Yayınları.

Özservet, Y. Ç. (2015). Aile dostu kent için kavramsal analiz. Şentürk, M. (Ed.), Aile dostu kentler etüt araştırması içinde, (ss. 53-68) Ankara: T.C. Aile ve Sosyal Politikalar Bakanlığı Aile ve Toplum Hizmetleri Genel Müdürlüğü.

Palmore, Erdman, B. (1990). Ageism: Negative and positive. New York: Springer Pub. Co.

Phillips, D. R., Oi-Ling S., Anthony Y. ve Kevin C. (2005). Ageing and the urban environment. G. J. Andrews ve D. R. Phillips (Ed.), Ageing and Place: Perspectives, Policy, Practice içinde. (ss. 147-163). London: Routledge.

Renaut, S., Ogg, J., Petite, S. ve Chamahian, A. (2015). Home environments and adaptations in the context of ageing, Ageing \& Society, 35(06), 1278-1303. Doi:10.1017/S0144686X14000221

Sabia, J. (2008). There's no place like home. Research on Aging, 30(1), 3-35.

Serdal, Ö. Ğ. Ü. T., Düzen, K. Ö., ve Polat, M. (2017). Huzurevlerinde yaşayan yaşlıların yerinde yaşlanma konusundaki duygu ve düşünceleri. Celal Bayar Üniversitesi Sağlık Bilimleri Enstitüsü Dergisi, 4(1), 522-526. 
Sixsmith, A., ve Sixsmith, J. (2008). Ageing in place in the United Kingdom. Ageing International, 32(3), 219-235. doi:10.1007/s12126-008-9019-y

Smith, A. E. (2009). Ageing in urban neighbourhoods: Place attachment and social exclusion. Portland, OR: Policy.

Strauss, A. L. Ve Corbin, J.M. (1998). Basics of qualitative research: Techniques and procedures for developing grounded theory (3. bs.). London: Sage

Şentürk, M., Ceylan, H. (2015). İstanbul'da yaşlanmak İstanbul'da yaşlıların mevcut durum araştırması. İstanbul: Açlım Kitap.

Tang, F. ve Lee, Y. (2011). Social support networks and expectations for aging in place and moving. Research on Aging, doi:10.1177/0164027511400631

Timmerman, S. (2012). To age in place or not... that is question. Journal of Financial Service Professionals. 66(1), 24-26.

Tufan, İ. (2003). Modernleşen Türkiye'de yaşlllık ve yaşlanmak: Yaşlanmanın sosyolojisi. İstanbul: Anahtar Kitaplar.

Türkiye İstatistik Kurumu (TÜIK) (2016). Aile yapısı araştırması. Ankara: TÜIK.

WHO | (2007). Global age-friendly cities: a guide. 29 Mart 2021 tarihinde, http://www.who.int/ageing/ publications/age_friendly_cities_guide/en/ adresinden erişildi.

Wiles, J. L., Leibing, A., Guberman N., Reeve, J. ve Allen, R. E. S. (2011). The meaning of "aging in place" to older people. The Gerontologist, 52(3), 357-366. 